\title{
REVIEWING STUDENTS' VOCABULARY MASTERY BY USING KAHOOT AT HOLMESGLEN PARTNERING WITH UNIVERSITY OF MUHAMMADIYAH TANGERANG
}

\author{
Muhammad Abduh Al-Manar ${ }^{1}$ \\ ${ }^{1}$ Muhammadiyah University of Tangerang \\ Email: abduh.almanar33@gmail.com
}

\begin{abstract}
The present study investigated the use of Kahoot as the free game-based learning platform which provided the students with ongoing feedback on their learning progresses. Reviewing the students' vocabulary was the focus of this study. Unlike summative test that tended to have formal assessment, Kahoot provided a learning with engagement and responsive feedback both students and teacher. In term of student's vocabulary mastery, Kahoot was the learning model of this study. Blended learning was applied technically in this study so that the students' vocabulary mastery was reviewed and tested through the application of Kahoot accessed by students' mobile phones. The methodology of this study was based on a questionnaire survey that was conducted to determine the use of Kahoot to the students' vocabulary mastery. More detail information was also added through observation, field note and interview. The 20 students of UMT (University of Muhammadiyah Tangerang) from Holmesglen English class were the population and samples of this study.
\end{abstract}

\section{Keywords: EFL Learning, Kahoot (Free Game-Based Learning Platform),Vocabulary mastery, Vocabulary review}

\section{INTRODUCTION}

Innovative ideas and creating awesome learning experiences to the students are necessary to teaching in this millennial era. Phil Mc Kinney (2017) described that "Using innovative teaching methods to have better serving to the students and to teach them about the benefits of innovative thinking, does so much more than just fill the pail". Integrated teaching and learning was important. A teacher with various teaching methodology understood better to the characters of the students' learning styles. Technology as its best, advantage the teacher and the students. With the help of the technology, immediate test or quizzes can be made instantly. Believing that 
technology like gadget, smartphone and internet create different learning atmosphere, blended learning seemed to be important to conduct for the students in the millennial era. Online learning which is one of the type of technology based learning allowing the students to have different learning experience. Dempsey \& van Eck (2007) stated that "online learning allows for a multitude discussions and socialization when experiencing and defining knowledge through social context".

The students' zaman now or millennial students (a student at the moment) is very familiar with the technology. Technology is becoming a part of their life. Applications that are installed on their phones connected them into their study, work and social networking. Therefore, the millennial students are now had changed the way live, do the task and communicate to others. There was a study determining whether Wiki technology can significantly improve the students' writing skill. Students participating in the study reported that their receiving immediate feedback from the instructor was a benefit of using this form of technology. Students in the study also reported learning vocabulary, spelling, and sentence structure by reading the work of their classmates (education research, Lin and Yang 2011).

Receiving immediate feedback and responses from the instructor is one of the features in kahoot. Direct feedback and result from kahoot helped the teachers to create effective time assessment to the students in the same time. The researcher believed by integrating our learning methodology to the curriculum in digital and technological world would gave significant effect of their learning performance. If their learning environment mirrors the ways in which they engage with the world, they will excel in their education explained by (Christen, 2009).

This study was also modeled the use of technology in reviewing the student vocabulary mastery. In line with the previous references, A study was conducted that the effect of information and communication technologies on students' math and science achievement with 4,996 students in Turkey. It showed that the students' exposure to Information and communication technology at home and school had a positive impact on their math and science achievement scores. Students' who spent a lot of time using technology were shown to have increased science knowledge. They also performed better on math skills. Information and communication technology has a positive effect on student learning and should be included in classroom instruction (Bulut \& Delen, 2011). 
According to Kurt (2010), "Technology can be used as a tool for establishing meaningful projects to engage the students in critical thinking and problem solving skill". Technology can be used to restructure and redesign the classroom to produce an environment that promotes the development of higher-order thinking skills. The referenced above described that technology was able to build the students critical thinking skill, collaborative, communicative and creativity.

\section{THEORITICAL REVIEW}

A. Technology as the powerful contributor in learning

Technology gave a new environment and atmosphere to the learning. Started from the last centuries, technology was developed for multiple purposes and education is a part of the purposes. (Johan Brand and Jamie Brooker, 2018) "Kahoot! is a game-based learning platform, free for teachers of awesome and classroom superheroes. Play, learn, have fun and celebrate together". Kahoots are best played in a group setting, for example, a classroom. Players answer the questions on their own devices, while games are displayed on a shared screen to unite the lesson (Johan Brand and Jamie Brooker, 2018). By implementing kahoot, this study created a quiz integrated with the students' mobile phones. The students' scores result and average were displayed in the projector calculated automatically after the quiz. Therefore, fast feedback and result of quiz are instantly done by the application.

Unlike formative test, summative test was easily conducted by the teacher. within a few minutes. The students' weaknesses were also described in detail in form of excel and tables. As a result, the students were easily identified and analyzed their vocabulary mastery better. It was mentioned in the by Zhao and Cziko (2009) that "Computer self-efficacy in pre-service teachers had a significant impact on their ability to integrate computer technology use in the classroom". Therefore, it will work together between teacher's competency in technology and world digital class in education. Technology had brought a lot of changes to the education. Kahoot is a collaborative which was the instructor or teacher in the classroom provided students centered learning.

By technology, the teacher is allowed to create real time assessment so that it can encourage the students and teacher to build digital learning environment in the classroom. Keane (2012) described the characters and types of digital learning: 
1) Digital teaching materials: It emphasizes that learners could learn by extracting some digital teaching material contents. The so-called digital teaching material contents refer to e-books, digitalized data, or contents presented with other digital methods.

2) Digital tools: It stresses on learners proceeding learning activity through digital tools, such as desktop computers, notebook computers, tablet computers, and smart phones.

3) Digital delivery: It emphasizes that learners' learning activity could be delivered through the Internet, e.g. intranet, internet, and satellite broadcasting.

4) Autonomous learning: It focuses on learners engaging in online or offline learning activity through digital learning by themselves. It stresses on personal autonomous learning and requires the participation of learners with autonomous learning to precede learning activity.

Kahoot played as the tool and media of learning. Integrated methods use and bringing the students into a digital classroom environment. The four types of digital learning above; digital learning material, digital tools, digital delivery and autonomous learning were included in kahoot. In a conclusion, kahoot creates an awesome learning tool for teachers. It provided the students to:

a) create a fun learning game in minutes which is related to the learning objective

b) work in group setting of players encourage players to look up and celebrate together

c) allow the students to do homework at home with kahoot.

Graham Gibbs quoted "Feedback should be timely in that it is received by students while it still matters to them and in tha time for them to pay attention to the further learning assistance " (Gibbs, 2010 p.3).

Chickering and Gamson (1987) stated that "Seven principles of good practicein undergraduati education' stating that, 'assessment without timely feedback contribbutes little to learning" the use of technology in giving students' feedback and assessment will create effective timely feedback. The learning progress of the students will be captured easily either the teacher or the students so that big number of the students will not be the obstacles by the presence of technology in education especially Kahoot.. 
Today's children use modern technical equipment from an early age (Gutnik et al., 2011; Rideout 2011) so that their coming in with new educational technologies at school will not be a problem.

B. Using Kahoot in reviewing the students vocabulary

Teaching vocabulary had to be continuous. The students need to learn a vocabulary through meaniful and applicative activities. It was so beacause vocabulary teaching technique should be done through productive and applicative activities. Walker (2011) said that “applicability of the use of a particular app has not been investigated from language teachers' point of views when in fact they are the instructional decision makers of a particular educational material". Thornbury (2002) argued that "teaching words is a crucial aspect in learning a language as languages are based on words". Kahoot has its best practices in reviewing students' vocabulary mastery. It showed from kahoot application where results and students' mistakes were viewed in excel exactly after the quiz done. Kahoot allowed the students to see their progresses in the real time. It also helps the students to monitor their progresses day by day. These were the steps that the students should do to join kahoot:

1) Selecting Kahoot that you wan to play: teacher and students sign in their accound through gmail from www.kahoot.com

2) Selecting the course that had been made by the teacher before.

3) Asking the students to join the the course by entering the game pin

4) Automatically the students joined the game of the course

It was also stated by David J.Nichol and Debra M. Dick (2010) that "feedback provides evidence about progress and achievement, rather than high stakes summative assessment tasks where evidence is only about success or failure or about how students compare with their peers". Without any doubt and hesitation, the implementation of technology through kahoot application was definitely effective.

C. Vocabulary Review and Assessment

Giving review and feedback in assessing the students' vocabulary is important. Giving positive feedback to the students will stimulus students' information. Kahoot also helped the students to remember the vocabulary that had been taught at the previous meeting. Therefore, students was actively and engaged the session in vocabulary review done by the teacher through 
kahoot. Giving immediate feedback is also stated by Piccinin (2003) that "at the time of providing feedback it is important that after reading that a student should have a positive feeling about that". The students' vocabulary will be reviewed and tested through the quizzes done by kahoot so that the students' vocabulary improved on each day of the meeting. Chall and Jacobs (2003) explained that "students' word knowledge is linked strongly to academic success because students who have large vocabularies can understand new ideas and concepts more quickly than students with limited vocabularies". Having a great vocabulary mastery will bring the students to have better chance to understand and master the language. Kahoot played as the tools of reviewing student vocabulary mastery.

Deciding which kind of vocabulary to test and review is another important decision that the language teacher has to make. Heaton (1990) said "it is important at the outset that you decide which words you expect your students to recognize (i.e., their passive or receptive vocabulary) and which words you expect them to use (i.e., their active or productive vocabulary)". Selecting the appropriate kind of vocabulary test is very important. In this study, the researcher reviewed the students' vocabulary mastery. The researcher reviewed the students' vocabulary mastery from how they use the vocabulary in the context of learning and pronounce it well in producing it.

D. Reviewing Vocabulary through Kahoot

Dwyer, Ringstaff, and Sandholtz (1991) stated that "computer technology changes the way teaching occurs. These changes include (1) a move from the teacher as the dispenser of knowledge to the teacher as a facilitator, (2) more opportunity for individualized instruction, (3) spend less time lecturing to the whole class, (4) more comfortable with small-group activities, and (5) team teaching”.

Using Kahoot as the tool of students' vocabulary review is an exciting way which is real time review directly seen and monitored. In this moment the teacher: (a) set classic mode of the game, (b) give the students words to remember on each day of lesson after the class, (c) reviews the students' vocabulary by using classic mode quiz which results and score will show directly after the game, and (d) rewards would be given for the top 5 on each day to motivate the students. 


\section{METHODOLOGY}

The student of University of Muhammadiyah Tangerang (UMT) was the subject of this study. There were twenty five students of UMT Indonesia who were taking an English class program at Holmesglen which is partnering with UMT Indonesia. The researcher conducted a survey to the samples of twenty students in the class.

a) Objectives

Investigating the students' interest in using technology; Kahoot to their learning performance in vocabulary mastery

b) Hypotheses

There are a significant correlations between students' interest in using technology; Kahoot in their learning performance in vocabulary mastery.

c) Research question

1. Does technology give significant impact to the students' learning motivation?

2. How does kahoot give significant effect to the Students' vocabulary mastery?

3. What are lived experienced of kahoot in improving students' vocabulary review?

d) Research methods

The study was based on questionnaire-based survey methodology and a questionnaire with 20 items referring to the students' responses and experiences which is described; (4) Strongly Agree, (3) Agree, (2) Disagree, (1) Strongly Disagree. The questionnaires were administered in the classroom after 10 sessions of meetings.

d) The research group

The research was carried out on a sample $(\mathrm{N}=20)$ of students from different faculties. There were 4 faculties in the groups, there were; engineering, teacher training, law and economic.

\section{FINDING}

This study was conducted to investigate whether the students' interest in using technology can be used to improve students learning performance. It was found by the researcher from the interviewed that the students mostly had difficulties in memorizing and using vocabulary in their daily conversation. As a result, the students mostly reviewed the vocabulary by memorizing, remembering and creating sentences but none of them used vocabulary in their daily conversation. Therefore, there were some factors that caused students' difficulty in learning 
vocabulary (1) lack of practices (2) the pronunciation of the written and spoken form (3) the influences of students' native language.

This study answered the following research question above from the questionnaire survey done by the researcher.

a. Technology had a significant impact to the students' learning motivation

It showed from the interview done by the researcher. They mostly experienced the joy of learning using technology. One of the students stated "I have never felt the excitement of learning through technology". Excitement and joy of learning was there.

b. Kahoot gave significant effect to the students' vocabulary mastery.

Through the spirit of the student in using technology, the students' vocabulary mastery was significantly improved. Competition and real time feedback and fast responses from the application of kahoot gave the students real time vocabulary review. It also measured the students' vocabulary progresses clearly through form of excel. Therefore, the teacher would easily identify the students' weaknesses to master the vocabulary.

It supported by a total of 15 questionnaires that were distributed to 20 students of Holmesglen Indonesia. The questionnaires were the base for computing the results. Strongly agree $58.33 \%$, agree $37.33 \%$, disagree $4.00 \%$ and strongly disagree $0.33 \%$ were the result from the questionnaires.

c. Kahoot gave the students experiences of integrated language learning in students' vocabulary mastery.

The students were engaged into activities of a class competition provided in the application of kahoot. The students were working in the group creating question related to the vocabulary. The class selected the option "Team Mode" which was allowed the student to work together in a team against other teams. Baxter and Gray (2001) said that "for effective learning it is desirable to move toward a model in which students are actively engaged in the learning process". The students centered learning was applied in the use of Kahoot. learning was centered to the students through activities provided in the Kahoot.

\section{CONCLUSIONS}

This table showed that only $0.33 \%$ of the subjects were strongly disagree of using kahoot. It was much higher to the strongly agree which was reached $58.33 \%$ from the samples. The 
results were based on the subjects' experiences and not on speculation or what they believed or thought of kahoot. It was also interested to note that there were high number of students' interest in the use of technology in learning. It also answered that there was a significant correlations between students' interest in using technology; Kahoot to their vocabulary mastery. It also described that there was a correlation between students' interest in using technology to their learning motivation and performance.

Figure 1: Result of questionnaire survey using Kahoot to review students' vocabulary mastery

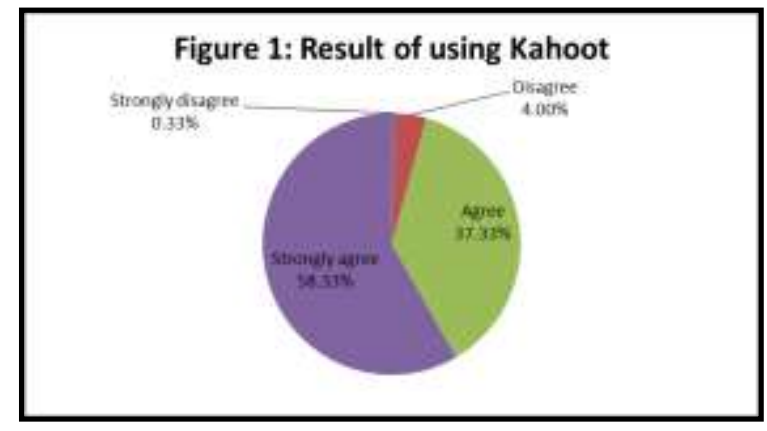

\section{REFERENCES}

Baxter, S., \& Gray, C. (2001). The application of studentcentered learning approaches to clinical education. International Journal of Language \& Communication Disorders: Supplement, 36, 396-400.

Bulut, O., \& Delen, E. (2011). The relationship between students' exposure to technology and their achievement in science and math. The Turkish Online Journal of Educational Technology, 10(3)

Christen, A. (2009). Transforming the classroom for collaborative learning in the 21st century. Techniques: Connecting Education and Careers, 84(1), 28-31.

Chall, J.s. \& Jacobs, V. A. (2003). Poor children's fourth-grade slump. American Educator, Spring, 2003. American Federation of Teachers.

Dempsey, J.V. \& Van Eck, R.N. (2007). Trends and Issues in Instructional Design and Technology Reiser, R.A. \& Dempsey, J.V. (Eds.). Upper Saddle River, NJ: Pearson.

Dwyer, D., Ringstaff, C., \& Sandholtz, J. (1991). Changes in teachers' beliefs and practices in technology-rich classrooms. Educational Leadership, 48(8), 45-52.

Heaton, J.B. (1990). Classroom testing. Harlow, UK: Longman. 
Johan Brand and Jamie Brooker, Co-Founders of Kahoot." Kahoot for school, Retrieved from https://kahoot.com/what-is-kahoot/ accessed 15 October. 2018.

Keane, D. T. (2012). Leading with Technology. The Australian Educational Leader, 34(2), 44.

Kurt, S. (2010). Technology use in elementary education in Turkey: A case study. New Horizons in Education, 58(1), 65-76

Kahoot. (2018). Game-based blended learning \& classroom response system. Retrieved October 16, 2018, from https://kahoot.com/what-is-kahoot/

Lin, W., \& Yang, S. (2011). Exploring students' perceptions of integrating Wiki technology and peer feedback into English writing courses. English Teaching: Practice and Critique, 10(2), 88-103.

McKinney, P. (2017) Innovation in the Classroom: Why Education Needs to Be More Innovative. Blog and Culture, Retrieved from http://philmckinney.com/innovationclassroom education-needs-innovative/ accessed June $5^{\text {th }} 2018$

Nicol, D. (2010). From monologue to dialogue: improving written feedback processes in mass higher education. Assessment \& Evaluation in Higher Education, 35(5), 501-517.

Piccinin, S. J. (2003). Feedback: Key to learning. Halifax, NS: Society for Teaching and Learning in Higher Education.

Thorburry, S. (2002).How to teach vocabulary.England:Pearson Education Limited.Ur, P., (1998). A course in language teaching. Cabridge University Press.

Walker, H. (2011). Evaluating the effectiveness of apps for mobile devices. Journal of Special Education Technology, 26(4), 59-63.

Zhao, Y. (2003). Recent Developments in Technology and Language Learning: A Literature Review and Meta-analysis. CALICO Journal, 21(1), 7-27. 